\title{
A Bibliometric Approach to the Publications in the Field of International Business in the Scopus Database
}

\author{
Jose Jaime BAENA ROJAS ${ }^{1}$, Camilo SÁNCHEZ GARCÍA ${ }^{2}$ \\ And Duvan GRAJALES RAMÍREZ ${ }^{3}$ \\ ${ }^{1}$ Institución Universitaria CEIPA, Medellín, Colombia \\ 2,3Tecnológico de Antioquia (TDEA), Medellín, Colombia
}

Correspondence should be addressed to: Jose Jaime BAENA ROJAS; jose.baena@ceipa.edu.co

Received date: 1 October 2019; Accepted date:19 November 2019; Published date: 14 January 2020

Academic Editor: Felipe Machorro Ramos

Copyright (C) 2020. Jose Jaime BAENA ROJAS, Camilo SÁNCHEZ GARCÍA And Duvan GRAJALES RAMÍREZ. Distributed under Creative Commons Attribution 4.0 International CC-BY 4.0

\begin{abstract}
This article carries out a bibliometric characterization of research in the field of international business, manifested in the academic literature that is indexed in the Scopus database, as is the case of scientific articles and other means of publication. On a methodological level, a descriptive study is carried out based on the measurement system of Scimago Journal \& Country Rank (SJR). Therefore, the results show the historical behavior of the media categorized by continents; the countries with the largest amount of literature; the total number of journals per quartile; and additionally identify some indicators that can influence research production in the field of study. It is concluded that the developed countries with significant budgets for research such as the United Kingdom, the United States, the Netherlands, Germany, among others, are currently the countries with the highest output of scientific publications indexed in Scopus.
\end{abstract}

Keywords: Scientific Publications, International Business, Field, Bibliometric.

\section{Introduction}

According to Valbuena \& Montenegro (2017), the dynamics of world trade have led to the study of international business becoming more and more prominent at a theoretical level due to the interest of scientific research to delve into topics of this discipline such as internationalization, competitiveness, selection of markets, analysis of strategies, costs, finances, organizational culture, international trade, and entrepreneurship. All of this, among other classic topics such as protectionism where new phenomena tend to arise all this considering the dynamics of

Cite this Article as: Jose Jaime BAENA ROJAS, Camilo SÁNCHEZ GARCÍA And Duvan GRAJALES RAMÍREZ (2020)," A Bibliometric Approach to the Publications in the Field of International Business in the Scopus Database ", IBIMA Business Review, Vol. 2020 (2020), Article ID 213756, DOI: 10.5171/2020. 213756 
international trade and the depletion of natural resources (Baena, 2019a). Buitrago (2015) adds that this prominence stands out at the applied level since within academia there is an increasing interest in training professionals and specialists in the field to develop specific skills in order to face all the challenges involved with the internationalization within the foreign trade of each state.

Cardona (2017) states that the occurrence of world trade has led not only to an indepth study of the multilateral trading system, where issues such as trade policies, protectionism and free trade are highlighted in addition to issues such as the study of the international monetary system in which case issues such as exchange rates and the currency market stand out. The foreign trade of countries takes on an increasing relevance within exchange operations in an increasingly independent scenario that is susceptible to economic crisis (Baena, Montoya, \& Torres, 2017), given that globalization also supposes significant deregulation of the policies among the countries at a general level successively leads to a paradigm of supranationality; as is the case with the different international organizations and their legal systems which exercise a deep role within the international system (Fernández, 2009; Baena \& Fernández, 2016; Baena, 2018; Baena, 2019).

All of the above implies strengthening the academic production in international business and internationalization in order to remark key research theories, contexts, features, methodologies, applications, limitations and opportunities about this entire field. Then, this discipline is identified as a research field with their own theories, highlighting their source and evolution in the last two centuries considering the consolidation of different issues that have led the international business as a strict discipline which attract the attention similarly of business practitioners and scholars and that is why biblimetrics for identifying literature in a specific field is increasingly important (Anzo, 2012; Gonzalez-Perez \& VelezOcampo, 2019).
Hence, the role of international business has been enhanced thanks to the scientific production of new knowledge in the field. This has been amplified through various databases on the Internet, allowing for the vast and remarkable amount of new research to be published through these means (Thelwall, 2018). In fact, within the research and development (R\&D) policy of many countries, reference databases are identified, (as is the case with Scopus of the Elsevier group), due to their remarkable number of citations that ultimately grant an outstanding academic and scientific impact to its publications (RodriguezMorales, Ochoa-Orozco, \& Mayta-Tristán, 2014).

A review of the literature allows for an understanding of the growth of international business as a discipline through which scientific research is carried out. Likewise, at the methodological level, the use of secondary sources that are published in 2016 by the database of Scimago Journal \& Country Rank (SJR) allow for the identification of the most prominent continents and countries by their means of publication. Furthermore, one can see the number of journals and their historical behavior. This allows for the understanding, in general terms, of key bibliometric aspects of scientific publications in the field of international business and the most prominent regions.

\section{International Business as a Discipline in Scientific Research}

In accordance with Buckley (2009), the discipline of international business has been built on the structuring of hypotheses derived from problems, in this specific case within internalized companies, which are validated after carefully analyzing different types of data gathered from comparative methods over time thus generating, through empirical results, a new theory within the field. Likewise Geoffrey \& Tarun (2004) they affirm that in this field of study it is necessary to provide new methodologies to understand research problems since international business, as a discipline, is essentially dynamic; this is why problem development can only be 
approached satisfactorily from a historical perspective.

Daniels, Radebaugh, \& Sullivan (2007) define international businesses as the exchange of goods and services that are carried out between countries. These activities are comprised of operations and sales contracts, in addition to other commercial exchange alternatives including but not exclusively franchises, joint ventures, direct foreign investment. These activities are carried out between companies that have commercial operations in different countries and a formal system of investment and alliances which increase the revenue or tax intake of the countries involved in a highly competitive market.

It should also be said that within international business there are several options through which states seek to liberalize trade with others and facilitate their companies' increased participation in different markets worldwide (Cardona, 2015). Strikingly, these new trends increasingly make intensive use of technological and computerized tools which point to the positioning of brands, facilitation of negotiation processes, revitalization of logistic processes, as well as other improvements (Roberts \& Fuller, 2010; Cano \& Baena, 2013; Cano \& Baena, 2017; Baena, Malaver, \& Puerta, 2017; Cano \& Baena, 2018; Baena, Cano, \& Campo, 2018).

It can be assumed that several centuries had to pass from the beginning of international business as a discipline before the specific study of the modern multinational company developed. During the first half of the nineteenth century, the economic model was mainly dependent on the extraction of materials from colonial territories. Subsequently, at the end of the 19 th century and the beginning of the 20th century, the organization of companies became more complex as organizations grew nationally and began to cross borders in search of new markets (Martínez, Corredor, \& Herazo, 2006).
Buckley (2002) affirms that the evolution of world trade has been a determining element in the field of international business and that it continues to advance at a theoretical level as well. This is because new approaches tend to emerge around the study of organizational approaches where it is crucial to adopt more formal models of strategic planning and international alliances between companies. Similarly, in the twentieth century, the role of culture in internationalization has been given greater importance since it directly affects the operations of companies.

Even though Jerez (2007) argues that at present the world of international business goes beyond the exchange of goods and services since, in the 21st century, international business also focuses on the study of large flows of money and capital which despite its complexity and given the multiplicity of existing regulations in this regard tend to become more dynamic given the role of technology in general within the dynamics of economic globalization.

Therefore, it can be affirm that the field of international business has undergone considerable evolution in recent decades due to the number of academic contributions that present different perspectives on the way in which companies carry out their internationalization processes. That is why the introduction of new content tends to cause studies in this field to move from a broader context to increasingly specific issues that were not as relevant for academics previously (Portugal-Ferreira, Rosa-Reis, Isnard Ribeiro de Almeida, \& Ribeiro-Serra, 2013).

In this sense, it is possible to recognize the transcendence of international business as an academic discipline which makes stronger with the research and the curriculums in universities for the comprehension of organizational structures. That is why a selective review of the literature on international business also allows identifying different approaches to the formulation of new matters focused on the internationalization of business, the integration of associated 
areas and, finally, the understanding of multidisciplinary and strategic orientation; all of this, within this complex discipline (Laughton, 2005). A complexity that precisely consists in the fact that international business is a discipline, nowadays in progress, which besides is based on many other fields such as marketing, accounting, management, among others, generating a relevant debate within scholar community about the challenges in regard the identity of this study. Indeed, this, same situation is noticeable when in the enterprises the departments tend to merge with other departments such as management, marketing or strategy, accounting because of the degree of flexibility and multidisciplinarity of international business (Michailova \&Tienari, 2014).

Similarly, Mancera (2015) argues that the discipline and field of study of international business tends to take, at a theoretical and research level, an increasing interest into the importance of the operation of business networks of the economy in a state. In fact, Baena \& Hurtado (2017) show that in some countries such a considerable formalization has been presented in theoretical and applied terms and that undergraduate and postgraduate programs have been developed in international business. Therefore, it is finally possible to delve deeper and research the solution of specific problems within organizations in an increasingly globalized environment. It is possible to say that the discipline of international business is in constant growth due to the diversity of research topics in this field. Furthermore, it is clear that this discipline is a still young branch of knowledge (Anzo, 2012).

Hence, all of the above suggest international business do not have an exclusive approach focused in the analysis of business transactions; on the contrary, economic, political, legal, social and cultural environments are part of their study and field of development, which even introduces trough research their object of study in a wide multidisciplinarity. In this way, stakeholders of this discipline are actors in the internationalization processes, based on the analysis and interpretation of the global environment usually dynamic and continuously changing (Buitrago, 2015).

Therefore, international business as a discipline from an epistemological approach, see scheme 1 , must be analyzed as a human phenomenon, from various fields of knowledge; all this, from the complexity of the social sciences. Likewise, taking into account the perspective of the so-called international studies (International Economics, International Finance, International Law, Political Science and International Relations) because such knowledge provides key elements for the development of strategies that remain in time and that lead to the realization of agreements between firms (Castells \& De Ipola, 2006; Calle, 2008). 


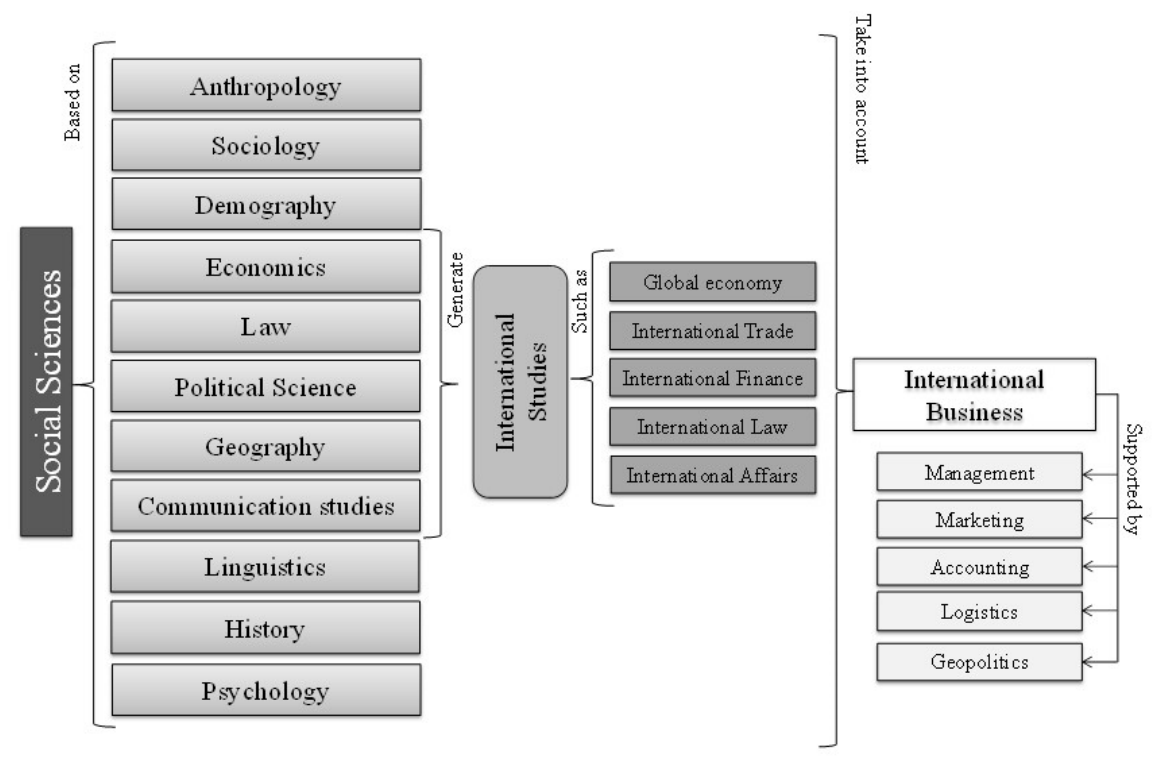

Scheme 1: Epistemological representation of international business

Source: prepared by the authors, based on Radebaugh, \& Sullivan (2007), Calle (2008) and Cohen \& Wartofsky (2013).

Precisely the construction of the field of international business depends in a significant way on scientific research that allows not only to identify the main topics of interest within this study but also to recognize the new approaches that are used for the solution of own issues that raise the rigor of this discipline (Valbuena \& Montenegro (2017; Vanegas, Restrepo \& Gonzalez, 2015). That is why also the bibliometrics in international business facilitates the systematic review of the literature and for the analysis of theories, contexts, characteristics, methodologies and opportunities for future research in this field (Gonzalez-Perez \& Velez-Ocampo, 2019).

In any case, Fatima (2017) points out that, at present, scientific research, indifferent to its field, is usually subject to the construction of academic articles. Therefore, it is interesting to note that the content of the journals tends to be more friendly in the presentation of the information regarding the content of the books and/or similar editorial works due to their synthetic structure and rigor in the citation patterns. Hence, Galvagno \& Dalli (2014) argue that scientific research has taken a decisive role for the generation of new knowledge since it aims to better understand the past, present and even the future state of the theory in a specific field. In addition, from a practical perspective, research has an impact on the verification of hypotheses in the construction of theories for decision making, especially teaching.

Additionally, according to Lahiri \& Kumar (2012), scientific production continues to grow at a rapid rate and academic institutions and schools are its leading architects since they constantly produce scientific material that tries to provide solutions to different problems within organizations. In fact, in the case of international business, the most prestigious journals in this field traditionally, until a decade ago, came from Scandinavia, the United States and the United Kingdom.

According to the contribution of Chan, Fung, \& Leung (2006), historically some of the most prestigious journals in the world, based on their quality and the number of specific citations within the field of international business, usually come from developed countries located in North America and Europe, although some Latin 
American countries have begun to show growth in recent years. In fact, this interesting evolution in the production of new literature about international business in Latin America can be explained by important networks of research that were carried out years ago between academic institutions from Iberoamerica (Murillo, 2003).

However, it is worth noting that not all researchers and readers know about the impact factor or quality rankings of publications. Journals are classified on the basis of production of knowledge which in turn is reflected in the number of citations. The number of citations, along with the validation of researchers, is a fundamental pillar upon which quality rankings can be quantified (Negahdary, 2017).

In the same way, Waltman (2016) emphasizes that the citations in scientific publications are of great importance for the evaluation of published research, and precisely this criterion is taken into account by renowned databases that consider the impact indicators of these citations due to increased stiffness and truthfulness within the scientific research. In consequence, it should be noted that from the perspective of research as well as bibliometric, it has been necessary to develop methodologies for the classification of journals and other means of publication within databases and platforms by reason of grouping, measuring, and quantifying the information contained in the papers and articles, allowing, in short, to establish quality and recognition thresholds among the different publications worldwide in scientific research such as SJR (Walters, 2017).

It can then be said that SJR provides a vast amount of information, which highlights for example, the number of documents published, the most cited documents, the total references thereof, among other aspects in a measurement system that provides an extensive statistical and informative content and which contributes considerably to the decision-making process within scientific research (Jacsó, 2009). As a consequence, Sáez (2017) argues that although it is true that there may be several databases for the dissemination of scientific material, it is also clear that one of the most relevant at present is the one developed by SJR that accounts for all the journals and other research papers that are indexed in Elsevier's Scopus database; a database which, according to González (2016) has come in a bibliometric reference as well as an evaluative reference for institutions and universities interested in specializing within the research field.

Precisely, International business as a discipline which is experiencing rapid growth, tend to adopt also all these parameters, described previously and related with research, for increasing the quality of the scientific literature in this regard. In this sense, the international business within the academia has strengthened even its role producing many different papers that also delve into its epistemological raison d'être of this relatively young discipline originated from Economics as a Social Science (Toyne \& Nigh).

\section{Methodology}

Initially, a review of the literature is carried out, consulting different databases such as Scopus in addition to Science Direct, Ebsco, Redalyc, Doaj, Scielo Google Scholar and even Google Books. This allows for the finding of different documents which delve into the topic of international business research as a field of study.

Then, at the methodological level, a general, mainly qualitative, review of the SJR web portal is carried out with the aim of analyzing different aspects of scientific journals and other means of dissemination. Therefore, this recognized source of consultation is then used in order to identify the total number of publications indexed in the Scopus database of Elsevier. It is possible to identify sources within the international business field and their respective categories with the filter "business management and accounting", a total of 344 publications during 2016. 
Subsequently, a descriptive study is carried out analyzing the information provided by SJR according to the search criteria previously indicated. This is how the results are developed allowing for different graphs to be built to display all this research.

\section{Results and Discussion}

Globally, scientific journals and media in the area of international business have undergone a significant evolution during the last three decades, (see Figure 1). This is due to multiple factors among which, for example, the expansion of globalization, the growth of international trade and successively the academy's interest in the topic that successively led to the formalization of international business as a discipline (Lewis, Moore, \& Dunning, 1999).

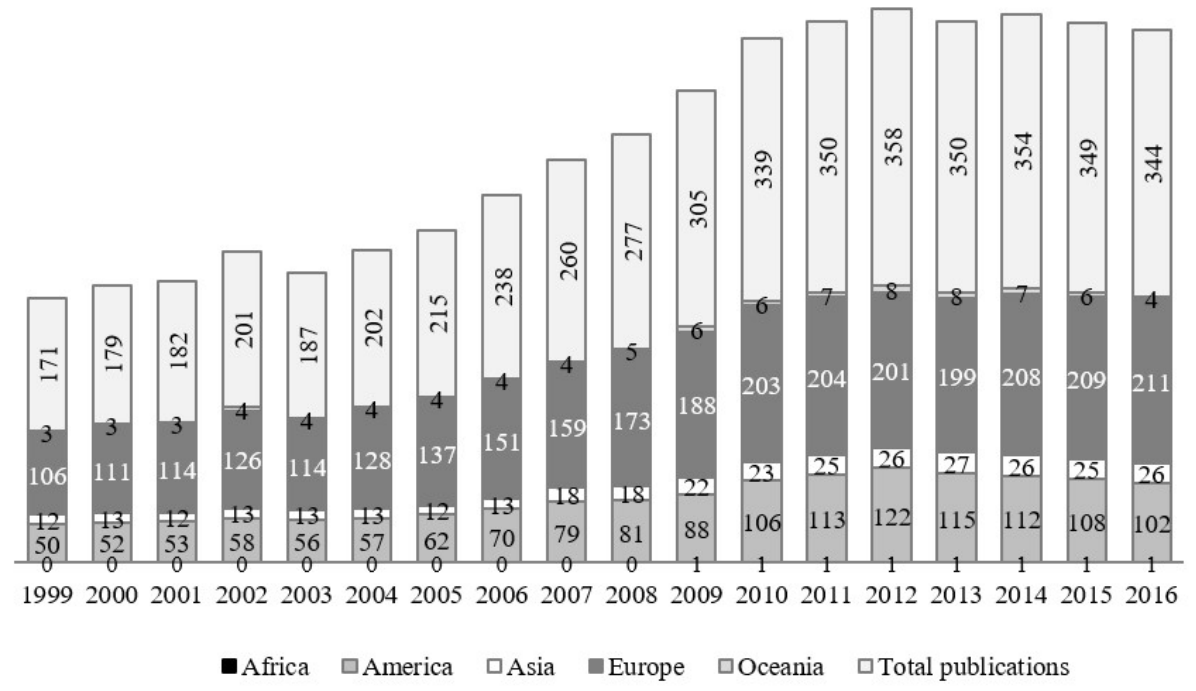

Fig.1: Behavior of scientific journals and media by continents (1999-2016) Source: prepared by the authors, based on SJR (2018).

According to Figure 1, there is an overall growth in the total number of magazines and publishing media since 1999, particularly in Europe and America, including Latin America. In fact, these two continents have practically doubled the number of their journals and means of scientific publications, increasing by $49.76 \%$ and $50.98 \%$ respectively. Thus, it can be said that continents such as Asia, Oceania and especially Africa still have fundamental challenges in the field of business research since their countries still have low values in relation to the leading regions.

In this section, it is possible to indicate the leading countries that stand out with more journals and number of publications found using indexation in the Scopus databases of Elsevier, see Figure 2. 


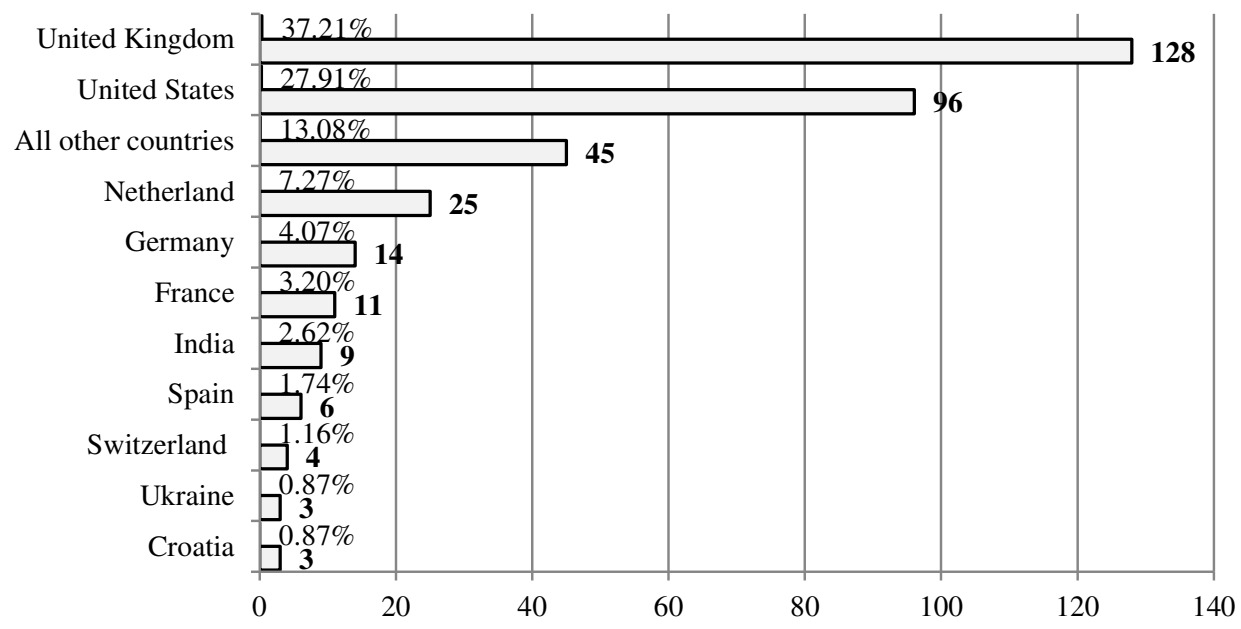

Fig. 2: Countries with the largest number of scientific journals and other media publications

Source: prepared by the authors, based on SJR (2018).

According to Figure 2, out of a total of 344 journals and other means of publication, the United Kingdom is the country with the most significant number, with a total of 128 journals, equivalent to $37.21 \%$. It is also worth highlighting the case of the United States that reaches a total of 96 journals equivalent to $27.91 \%$ and subsequently the Netherlands with a total of 25 journals which represents $7.27 \%$.
Regarding the occurrence by continents of the best journals and other means of publication, see Figure 3, according to the SJR website; in order to recognize by regions the contributions that they contribute worldwide to the field of international business within their geographical area.

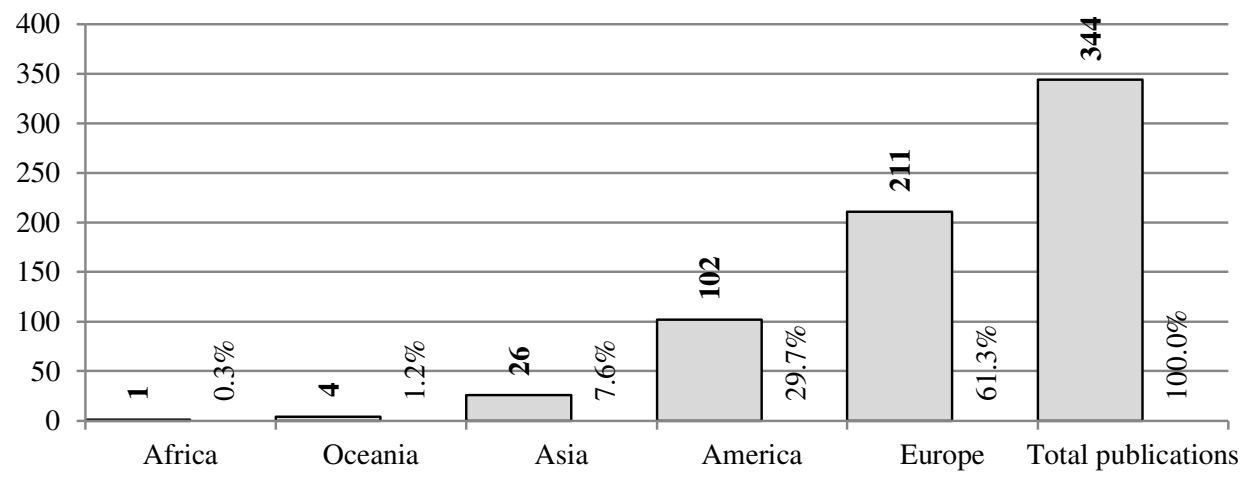

Fig.3: Continents with the largest number of scientific journals and other media publications

Source: prepared by the authors, based on SJR (2018). 
According to Figure 2, the number of scientific journals and media in the Scopus database is led by Europe, with a total of 211 journals and other publications which amount to $61.3 \%$. Europe is followed by America with a total of 102 journals and other publications equivalent in this case to $29.7 \%$ of the total publications together they amount to 313 or $91 \%$ of the journals. The remaining continents, Asia, Oceania and Africa together barely reach 31 journals and other publications. This is $9 \%$ of the total publications in international business.

It should be noted that publications indexed in Scopus, such as scientific journals are, according to the SJR measurement, mostly delimited by quartiles, see Figure 4, which in turn constitute an indicator exclusively related to quality.

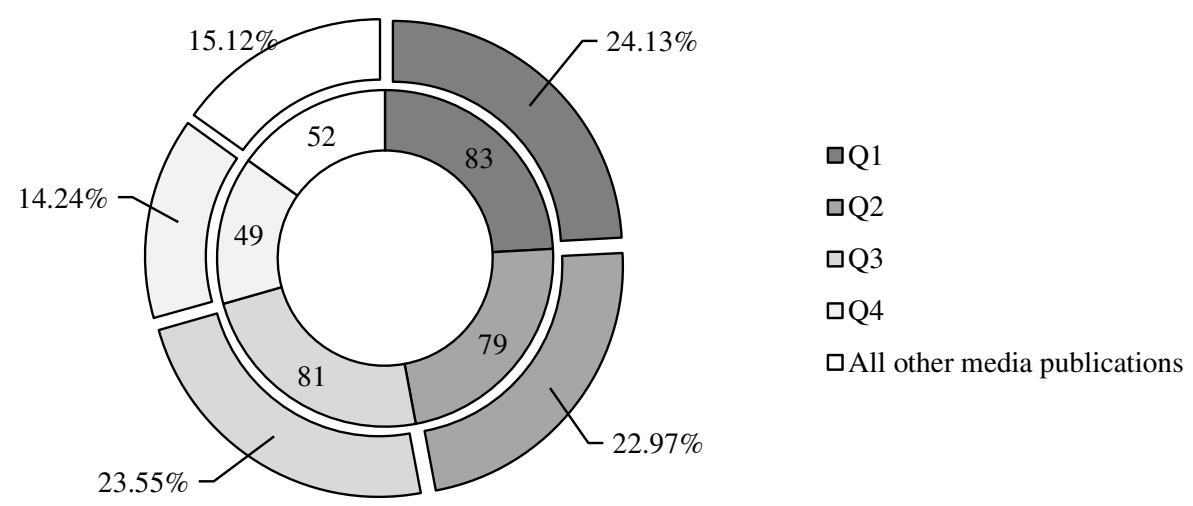

Fig.4: Quartiles of journals indexed in Scopus

Source: prepared by the authors, based on SJR (2018).

According to Figure 4, from the 344 published media indexed in Scopus, 292 correspond to scientific journals while the remaining 52 pieces of media are nonquartile publications such as book chapters, conference proceedings, etc. In other words, it can be said that $84.8 \%$ of the best-rated publications worldwide in the field of international business are journals, while the remaining $15.12 \%$ correspond to high-impact publication media without quartiles.
Finally, regarding the countries with the largest number of journals and media in the international business area, it should be noted that their positions worldwide may be due to factors related to the creation of public policies to promote R\&D in addition to economic components, see Table 1, which can lead to more significant creation of journals and scientific media. 
Table 1: Factors that can influence the number of scientific journals and media

\begin{tabular}{|c|c|c|c|c|}
\hline $\begin{array}{c}\text { Analyzed } \\
\text { Countries }\end{array}$ & $\begin{array}{c}\text { R \& D } \\
\text { expenditure } \\
\text { (\% of GDP) }\end{array}$ & $\begin{array}{c}\text { Global spending } \\
\text { on R \& D }\end{array}$ & $\begin{array}{c}\text { Staff in R \&D } \\
\text { (per million } \\
\text { people) }\end{array}$ & $\begin{array}{c}\text { People } \\
\text { graduated } \\
\text { with a PhD }\end{array}$ \\
\hline $\begin{array}{c}\text { United } \\
\text { Kingdom }\end{array}$ & $1,67 \%$ & 4.350 & 25.020 \\
\hline United States & $2,74 \%$ & 510.310 .615 .000 & 4.313 & 67.449 \\
\hline Netherland & $2,00 \%$ & 1.867 .119 .873 & 4.673 & 5.500 \\
\hline Germany & $2,92 \%$ & 101.551 .651 .215 & 4.748 & 28.147 \\
\hline France & $2,27 \%$ & 66.558 .626 .031 & 4.307 & 13.729 \\
\hline India & $0,62 \%$ & 4.818 .810 .758 & 216 & 24.300 \\
\hline Spain & $1,22 \%$ & 15.094 .511 .240 & 2.639 & 10.889 \\
\hline Switzerland & $3,37 \%$ & 24.743 .575 .345 & 5.257 & 3.990 \\
\hline Croatia & $0,85 \%$ & 19.330 .952 .540 & 1.503 & 3.451 \\
\hline Ukraine & $0,61 \%$ & 315.009 .371 & 1.037 & N.D \\
\hline
\end{tabular}

Source: prepared by the authors, based on The World Bank (2018) \& OECD (2016).

According to Table 1, there may be strategic indicators for the positioning of countries in the creation of journals and other means of scientific dissemination, in this specific case, for the field of international business.

It is clear how during 2016 two countries, the United Kingdom and the United States, produced almost a third of the business media with a total of 224 journals and other media. Their expenditure on R\&D allows for a greater number of researchers (people graduated with a PhD) who are usually qualified precisely to produce and promote scientific research initiatives.

\section{Conclusions}

The primary means of scientific publication in the field of international business is concentrated in some developed countries where the expenditure on $R \& D$, the number of researchers, and the number of academic researchers, among other elements, are usually considered as public policy. The data in Table 1 are significantly important in the case of countries such as the United Kingdom, the United States, the Netherlands and Germany, among other countries.

Likewise, the publications indexed in the Scopus database have a high academic recognition that is categorized into quartiles within the SJR measurement system, as is the case of scientific journals. Therefore, this measurement establishes four groups such as Q1, Q2, Q3 and Q4, the first being the highest and the fourth the lowest, which are the result of the quality, the impact factor, and other aspects which allow researchers within the field of international business, in addition to other fields and disciplines, to identify the best journals and other means of scientific publication.

In general terms, it can be affirmed that in recent years there has been a more than significant growth in the production of scientific knowledge within the field of international business. This is reflected in the number of journals and means of publication as evidenced in the SJR measurement system. As a result of globalization, there has been a greater interest in international business and, consequently, in more considerable research, in order to propose solutions for the internationalizing organizations.

\section{References}

1. Anzo, E. (2012). Negocios internacionales: evolución, consolidación e identificación de los temas que lideran el campo de investigación. Revista Ciencias Estratégicas, 20(27), 77-93. 
2. Baena, J. (2018). Barreras arancelarias y no arancelarias como restricciones al comercio internacional. Revista Venezolana de Gerencia, 23(83), 543562.

3. Baena, J. (2019). La política de comercio exterior y las exportaciones colombianas. Revista de Economía Institucional, 21(41), 51-70.

4. Baena. J. (2019a). Proteccionismo inverso y política comercial dentro del sistema multilateral de comercio: el caso de las restricciones a la exportación. Estudos Internacionais: Revista De relações Internacionais $D a$ PUC Minas, 7(3), 28-50.

5. Baena, J., \& Fernández, X. (2016). Aproximaciones a la inserción de Colombia en el sistema multilateral de comercio en 1995-2015 . Análisis Político, 29(87), 114-131.

6. Baena, J., \& Hurtado, A. (2017). Generalidades de los negocios internacionales como programa de educación superior en Colombia. Science of Human Action, 2(2), 269291.

7. Baena, J., Cano, J., \& Campo, E. (2018). Metodología para la Selección de Mercados Internacionales: Un Análisis de Caso para la Exportación de Bebidas Carbonatadas. Dirección y Organización, 66(1), 5-16.

8. Baena, J., Malaver, J., \& Puerta, P. (2017). Portales web: ¿estrategia para la consolidación de los pregrados de negocios internacionales? Espacios, 38(60), 1-21.

9. Baena, J., Montoya, A., \& Torres, D. (2017). La crisis económica mundial ¿La proliferación del proteccionismo como una causa-efecto? En-Contexto, 5(6), 185-207.

10. Banco Mundial. (2018). Investigadores dedicados a investigación y desarrollo (por cada millón de personas). Obtenido de

https://datos.bancomundial.org/indica dor/SP.POP.SCIE.RD.P6

11. Buckley, P. (2002). Is the International Business Research Agenda Running Out of Steam? Journal of international business studies, 33(2), 365-373.
12. Buckley, P. (2009). Business history and international business. Business History, 51(3), 307-333.

13. Buitrago, I. (2015). Tendencias de la disciplina en Negocios Internacionales. Revista Académica e Institucional Páginas de la UCP, 1(97), 109-121.

14. Cano, J., \& Baena, J. (2013). Retos en la implementación de las TIC para el proceso de negociación internacional. Cuadernos de Admistración, 29(50), 153-163.

15. Cano, J., \& Baena, J. (2017). Limitaciones en el uso y apropiación de tecnologías de información y comunicación para la negociación internacional en empresas colombianas. Observatorio, 11(1), 111133.

16. Cano, J., \& Baena, J. (2018). Appropriating ICT for International Business Negotiations Performance: A Case Study of the Pacific Alliance. Revista La Sallista de Investigación, 15(1), 102-112.

17. Cardona, G. (2015). La Organización Mundial del Comercio y los TLC ¿reinventando el Sistema Multilateral de Comercio? Medellín: Editorial CEIPA.

18. Cardona, G. (2017). Comercio Mundial tendencias y estructura. Medellín: Editorial CEIPA.

19. Cardoza, G., \& Fornés, G. (2011). International co.operation of IberoAmerican countries in business administration and economics research. European Business Review, 23(1), 7-22.

20. Castells, M., \& De Ipola, E. (2006) Epistemological practice and the social sciences. Economy and Society, 5 (2), 111-144.

21. Chan, K., Fung, H., \& Leung, W. (2006). International business research: Trends and school rankings. International Business Review, 15(4), 317-338.

22. Cohen, R., \& Wartofsky, M. (2013) Epistemology, Methodology, and the Social Sciences. Boston: Springer Science Business Media.

23. Daniels, J., Radebaugh, L., \& Sullivan, D. (2007). International Business: Environments and Operations. Pearson education. 
24. Fatima, N. (2017). Citation analysis of business research: An international journal in the field of business. DESIDOC Journal of Library and Information Technology, 37(4), 281286.

25. Fernández, X. (2009). Globalización económica, soberanía de los estados y políticas sociales: funciones y retos del derecho internacional ante el "Trilema" de la globalización. Sociedad Global revista de relaciones internacionales y ciencias políticas publicación de la Universidad Abierta Interamericana, 3(1), 43-84.

26. Galvagno, M., \& Dalli, D. (2014). Theory of value co-creation: A systematic literature review. Managing Service Quality, 24(6), 643-683.

27. Geoffrey, J., \& Tarun, K. (2004). Bringing History into International Business. Harvard Business School, 1(1), 1-24.

28. González, G. (2016). Bibliometría grado de información y documentación. Valencia: Edicions Culturals Valencianes.

29. Jacsó, P. (2009). SCImago journal rank, worldmapper, Atlapedia. Online (Wilton, Connecticut), 33(3), 50-53.

30. Jerez, J. (2007). Comercio internacional. Madrid, España : ESIC.

31. Lahiri, S., \& Kumar, V. (2012). Ranking International Business Institutions and Faculty Members Using Research Publication as the Measure: Update and Extension of Prior Research. Management International Review, 52(3), 317-340.

32. Laughton, D. (2005). The Development of International Business as an Academic Discipline. Journal of Teaching in International Business 16(3),47-70.

33. Lewis, D., Moore, K., \& Dunning, J. (1999). Birth of the Multinational: 2000 Years of Ancient Business History From Ashur to Augustus. Copenhagen: Copenhagen Business School Press.

34. Mancera, A. (2015). Negocios Internacionales: En un mundo globalizado. Ciudad de México: Grupo Editorial Patria.

35. Martínez, C., Corredor, A., \& Herazo, G. (2006). Negocios internacionales.
Estrategias globales. Bogotá: Editorial Universidad Santo Tomás.

36. Michailova, S. \& Tienari, J. (2014). What's happening to international business? University structural changes and identification with a discipline. Critical perspectives on international business, 10(1/2), 51-64.

37. Murillo, J. (2003). La investigación sobre eficacia escolar en Iberoamérica: revisión internacional sobre el estado del arte. Bogotá: Centro de Investigación y Documentación Educativa (CIDE).

38. Negahdary, M. (2017). Identifying Scientific High Quality Journals and Publishers. Publishing Research Quarterly, 33(4), 456-470.

39. OECD. (2016). OECD Science, Technology and Innovation Outlook 2016. Obtenido de Organisation for Economic Co-operation and Development: https://read.oecdilibrary.org/science-andtechnology/oecd-science-technologyand-innovation-outlook2016_sti_in_outlook-2016-en\#page149

40. Portugal-Ferreira, M., Rosa-Reis, N., Isnard Ribeiro de Almeida, M., \& Ribeiro-Serra, F. (2013). International Business Research: Understanding Past Paths to Design Future Research Directions. Philosophy of Science and Meta-Knowledge in International Business and Management, 26(1), 299330.

41. Roberts, J., \& Fuller, T. (2010). International business: past, present and futures. The journal of policy, planning and futures studies, 42(9), 901-909.

42. Rodriguez-Morales, A., Ochoa-Orozco, S., \& Mayta-Tristán, P. (2014). Impacto de las revistas de salud colombianas: comparación de Publindex versus Google Scholar Metrics, SciELO y SCOPUS. Revista Cubana de Información en Ciencias de la Salud (ACIMED), 25(1), 24-35.

43. Sáez, J. (2017). Investigación educativa fundamentos teóricos, procesos y elementos prácticos. Madrid: Editorial Universidad Nacional de Educación a Distancia. 
44. Scimago Journal \& Country Rank. (2018). Journals Rankings. Obtenido de Business Management and Accounting / Business and International Management:

http://www.scimagojr.com/journalran k.php?category $=1403 \&$ area $=1400 \&$ pa ge $=4 \&$ total_size $=344$

45. Thelwall, M. (2018). Microsoft Academic: A multidisciplinary comparison of citation counts with Scopus and Mendeley for 29 journals. Journal of Informetrics, 11(4), 12011212.

46. Toyne, B. \& Nigh, D. (1999). International Business: Institutions and the Dissemination of Knowledge. Columbia: University of South Carolina Press.

47. Valbuena, P., \& Montenegro, Y. (2017). Tendencias de investigación en negocios internacionales (2012- 2016).
Cuadernos Latinoamericanos de Administración, XIII(25), 9-18.

48. Vanegas, J., Restrepo, J., Gonzalez, M. (2015) Negocios y comercio internacional: evidencias de investigación académica para Colombia. Suma de Negocios , 6(13), 84-91.

49. Velez-Ocampo, J. \& Gonzalez-Perez, M. (2019) Analyzing foreign expansion and corporate reputation: review and future research agenda. Cross Cultural \& Strategic Management 26(4), 586608.

50. Walters, W. (2017). Citation-Based Journal Rankings: Key Questions, Metrics, and Data Sources. IEEE Access, 5(7), 22036-22053.

51. Waltman, L. (2016). A review of the literature on citation impact indicators. Journal of Informetrics, 10(2), 365-391. 